\title{
Fisheries of Ilaje Community, Badagry, Lagos, Nigeria
}

\section{Oluwayemisi A. Osodein* and Martins A. Anetekhai}

Department of Fisheries. Faculty of Science. Lagos State University. Ojo. Lagos. Nigeria.*Email: sodeinyemmy2013@gmail.com.

\begin{abstract}
This study examined the fisheries of Ilaje Fishing Community, Badagry, Lagos State. The species composition, length-weight relationships, correlation parameters of landings, fishing gears and crafts, post-harvest technology and socioeconomic profile of Fishermen were investigated. Species were sampled fortnightly from July to December, 2017 and respondents were sampled with structured questionnaire and discussion with key informants and focused group. The slope (b) values obtained for the 36 fish species from 22 families ranged from -1.5826 to 8.4126 with most of the fish species having negative allometric growth. Lowest condition factor (K) (0.321) was recorded in Trichiurus lepturus (Trichiuridae) while the highest value (20.304) was observed in Calappa rubroguttata (Calappidae). Majority of the canoe are motorized by 40 horse powered engine, with the fish species captured preserved with the use of traditional smoking kiln, while socioeconomic status of the fisherfolks is concluded to be average/low. Output of analyses of length and weight measurement of some species, which were landed in Ilaje Fishing Community, Badagry, Lagos State, Nigeria, which have not been reported, are available for referrer for further studies.
\end{abstract}

Keywords: Artisanal fishing; Specie composition; Fishing gears and craft; Post-harvest; Socioeconomic characteristics.
Received

September 26, 2019

Accepted

August 28, 2020

Released

December 31, 2020

Full Text Article

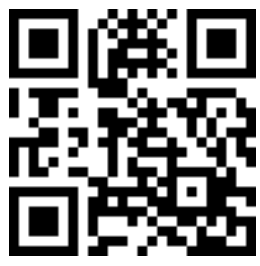

ORCID

D 0000-0002-1472-956X Oluwayemisi A. Osodein

D 0000-0001-5969-7832

Martins A. Anetekhai

\section{Introduction}

Fisheries sector is a viable sub-sector of agriculture which involve the commercial exploitation of aquatic products and its contribution to Nigeria's economy is enormous, such as provision of income to fishermen, employment opportunity, cheapest protein source and foreign exchange earnings. Fisheries contribute $85 \%$ of domestic fish consumption in Nigeria (Neimanis, 2005), with more than $98 \%$ of the population of fishing communities dependent on fishing and fishery related activities (SFLP, 2002).

Marine artisanal fishing generally involves good knowledge of local geography for effective and professional marine fishing. The fisheries development in the state are tailored along the available land and water resources with well-developed marine artisanal fisheries targeting the demersal and pelagic species within 0-5 nautical miles. 
Badagry is a coastal town and Local Government Area (LGA) in Lagos State, Nigeria. It is situated between the city of Lagos, and it border with Benin at Seme (Coordinates: $6^{\circ} 22^{\prime} 55^{\prime \prime} \mathrm{N}, 2^{\circ} 43^{\prime} 20^{\prime \prime} \mathrm{E}$ ). The fishing settlers migrated due to the water mass present in the area of Badagry and therefore engage in artisanal fishing making use of different form of fishing gears and craft and therefore form various rural fishing communities such Apa, Aradagun, Asakpo, Erikiti, Ganyaingbo, Ganyingbo town, Gayingbo,Gbaji yeke tome, Gbaji-Yekke, Gberefu, Hoke-daho, Ibereko,Igborosun, Ikoga, Ilado, Ilogbo, Imeke, Iragbo, Iworo, Koga, Kujinada, Kweme, Mosafejo, Pota, Sheik modawa, Toga, Tohun, Topo-Idale, Wesere and Yovoyan.

The present study area - Ilaje Community - is a coastal fishing community situated on the Gberefu Island and encompasses artisanal fisherfolks that embrace the use of motorized planked canoe for their fishing operation on the Atlantic Ocean. The fish resources landed in this fishing community include prawns, shrimps, crabs, oysters, rays, skates, and pelagic and demersal fish species among others.

The length-weight relationship of these fish species captured is an important way of managing and assessing the fish stocks. They are applicable in estimating the standing stock biomass, calculating condition indices and comparing the ontogeny of fish population from different regions (Odat 2003). The relationships between the length and the weight are related with metabolism in each species and the environment where they live (González-Gándara et al., 2003).

Less effort is put into the mechanization of fish processing as traditional methods are commonly used and some of these traditional fish processing methods are associated with contaminations which are mainly injurious to consumers (George 2014) and not environmentally friendly. It is believed that if the fish losses from postharvest activities could be reduced to the barest minimum, the gap between demand and supply of fish could be closed implying that the impact of governments' efforts through programmes/projects aimed at increasing domestic fish production could be meaningfully felt by the people especially the poor ones.

In recent times, over-exploitation of aquatic resources has become a serious problem. While aquatic resources have the ability to renew themselves under an appropriate management system, over-fishing and over-exploitation constrain the reproduction capacities of these resources. (George 2014) argued that coastal fish stocks have decreased to $30 \%$ of their unexploited levels as a result of overexploitation. As a consequence, poor coastal fishers who depend solely on these resources continue to experience poverty. These concerns call for the establishment of an appropriate fisheries management system to promote sustainable utilization of aquatic resources.

At present, there is a shortfall in meeting the fish demand of the teeming population of Nigerian. In an attempt to meet this demand, several billions of naira is spent annually on fish importation. Though, aquaculture has tried to cushion this shortfall effect but the vast majority of fish catch in Nigeria are still from artisanal fisheries. Therefore, the present study become important in order to assess the fairness, efficiency and problem of Ilaje community, so as to provide recommendation for augmenting the fish catches in this community without violating the regulation for conservation of fish biodiversity.

The study aimed to describe the catch composition of species landed, socioeconomic characteristics of artisanal fisherfolks, assess the cost structure and profitability of artisanal fishing, describe the factors that affect the sustainability of artisanal fisherfolks, identify the dominant fish species at the landing sites, identify the type of fishing gears and craft used at the location and their contribution to fish landing, describe the fishing methods, identify the fish preservation and processing methods and determine the role of men, women and children in Ilaje community in Badagry, Lagos, Nigeria. 


\section{Materials and methods}

The study was carried out in Ilaje Community, Gberefu Island, Badagry, in Lagos State. The Ilaje community (basically an artisanal fishing community) is a coastal settlement in Badagry sited along the shore of the Atlantic Ocean which was created in 1991, by the Ilaje settlers. Badagry is one of the coastal towns of Lagos State, located $57 \mathrm{~km}$ from Lagos on Latitude $6^{\circ} 23^{\prime}$ and $6^{\circ} 28^{\prime} \mathrm{N}$, and Longitude $2^{\circ} 42^{\prime}$ and $3^{\circ} 23^{\prime}$ E. The community was sampled fortnightly from July to December, 2017 during which observations were made on the fishing operations and data were collected through the administration of structured questionnaires, personal interviews and participation in direct measurement of fish. A total of sixty-eight randomly selected respondents were sampled with structured questionnaire. Furthermore, thirty-two fisher folks were purposively selected for the focus group discussion (FGD) in the communities. On the other hand, key informants and some individuals at the shore and within the community were also interviewed. The number of canoes used in fishing at each village was counted and dimension of each canoe were also recorded. Fish samples were randomly selected and purchased from fisher-folks, fortnightly at the landing site in Ilaje community. The fish samples were preserved in an ice-chest, containing ice cubes and transported to the Department of Fisheries Laboratory, Lagos State University for identification and measurement. At the laboratory, fishes were stored in a deep freezer to avert posthumous deterioration. Prior to length and weight measurements, the fishes were taken out in batches from the freezer and allowed to thaw. Identification was carried out using fish guides (Carpenter and De Angelis, 2016; Froese and Pauly, 2017; Pollerspöck and Straube, 2015). Total length (cm) of each fish was taken from the tip of the snout (mouth closed) to the extended tip of the caudal fin using a measuring rule to the nearest $0.01 \mathrm{~cm}$. Body weight was measured to the nearest gram using top loading Metler balance (Fafioye and Oluajo, 2005).

The Length-weight relationship (LWR) was derived from equation: $W=a L^{b}$ (Le Cren, 1951; Jones, 2002). The logarithm transformation of the equation was expressed as: Log W= Loga+ bLogL (Le Cren, 1951, Koutrakis and Tsikliras, 2003), where W=fish body weight in grams, $\mathrm{L}=$ fish total length in centimetres, $\mathrm{a}=$ intercept or constant and $\mathrm{b}=\mathrm{slope}$ or length exponent. Growth was regarded as isometry when the value of $b=3$ and allometry when less or greater than $3(\mathrm{~b}<3<\mathrm{b}$ or $\mathrm{b}<3, \mathrm{~b}>3$ ). The student's t-test was used to verify whether the parameter $b$ were significantly different from the expected or theoretical value of 3 (i.e $b=3, p<0.05)$. Thus, $t=(b-3) / s b(Z a r, 1984)$, where $t=$ student's $t$ test, $b=$ slope, $s b=$ standard error of the slope $s b=\sqrt{\left(\left[(s W / s L)-b^{2}\right] /(n-2)\right) . W h e r e}$ $\mathrm{sW}=$ variance of body weight, $\mathrm{sL}=$ variance of total length, $\mathrm{n}=\mathrm{sample}$ size. The correlation coefficient ( $r$ ) values were calculated from linear regression of the fish length and weight measurements. The determination of coefficient $r$ was used as indicator of the quality of the linear regressions. The condition factor was calculated by the formula: Condition Factor $(\mathrm{K})=100 \mathrm{~W} / \mathrm{L}^{3}$ (Pauly 1983), where $\mathrm{W}$ is the fish body weight and $\mathrm{L}$ is the fish total length. All data were analyzed using Microsoft Office Excel (2007) and Statistical Package for Social Science (SPSS version 20).

\section{Results}

A total of ninety-one plank canoes (Figue 1) were counted in Ilaje Community during this study. The canoes were constructed by Carpenters (each with two apprentices) who are also fishermen and live in the same fishing community. The canoes make use of 30 (two), 40 (eighty-four), 60 (four) and 70 (one) horse power (Figure 2) outboard engines. The length of the plank canoes used in exploiting the fish from the wild, ranged from $710 \mathrm{~cm}$ to $889 \mathrm{~cm}$ while the width of the Canoes ranged from $160 \mathrm{~cm}$ to $167.64 \mathrm{~cm}$,

Braz. J. Biol. Sci., 2020, Vol. 7, No. 17, p. 261-282. 
with depth of $110 \mathrm{~cm}-114.3 \mathrm{~cm}$. The length of canoe is proportional to the width. The mean lengths, width and depth of the canoes were $799.5 \mathrm{~cm}, 163.5 \mathrm{~cm}$ and $112.15 \mathrm{~cm}$ respectively. Shrimp net with different mesh sizes at the second layer, first layer and cod end were recorded (Table 1) at Ilaje Community, though with a distinct mesh size for fin fish and shrimp.

Table 1. Dimensions of shrimp net in use in Ilaje Community.

\begin{tabular}{|l|c|c|c|c|c|c|c|c|c|}
\hline & \multicolumn{3}{|c|}{ Mesh size (cm) } & \multicolumn{3}{c|}{ Length (cm) } & \multicolumn{3}{c|}{ Breadth (cm) } \\
\cline { 2 - 10 } & Min & Max & $\begin{array}{c}\text { Mean } \pm \\
\text { S.D }\end{array}$ & Min & Max & $\begin{array}{c}\text { Mean } \pm \\
\text { S.D }\end{array}$ & Min & Max & $\begin{array}{c}\text { Mean } \pm \\
\text { S.D }\end{array}$ \\
\hline First layer & 1.8 & 2.0 & $\begin{array}{c}1.88 \pm \\
0.08\end{array}$ & 457.2 & 460.6 & $\begin{array}{c}457.97 \pm \\
1.15\end{array}$ & 393.7 & 410.2 & $\begin{array}{c}401.47 \pm \\
5.48\end{array}$ \\
\hline Second layer & 1.0 & 1.2 & $\begin{array}{c}1.12 \pm \\
0.06\end{array}$ & $1,000.76$ & $1,010.2$ & $\begin{array}{c}1,004.14 \pm \\
3.30\end{array}$ & 241.3 & 250.6 & $\begin{array}{c}246.66 \pm \\
3.29\end{array}$ \\
\hline Cod end & 0.5 & 0.8 & $\begin{array}{c}0.65 \pm \\
0.11\end{array}$ & $1,524.0$ & $1,535.0$ & $\begin{array}{c}1,528.4 \pm \\
4.56\end{array}$ & 63.5 & 65.5 & $\begin{array}{c}64.48 \pm \\
0.63\end{array}$ \\
\hline
\end{tabular}

${ }^{*}$ Min $=$ Minimum, Max = Maximum, S. D. = Standard deviation.

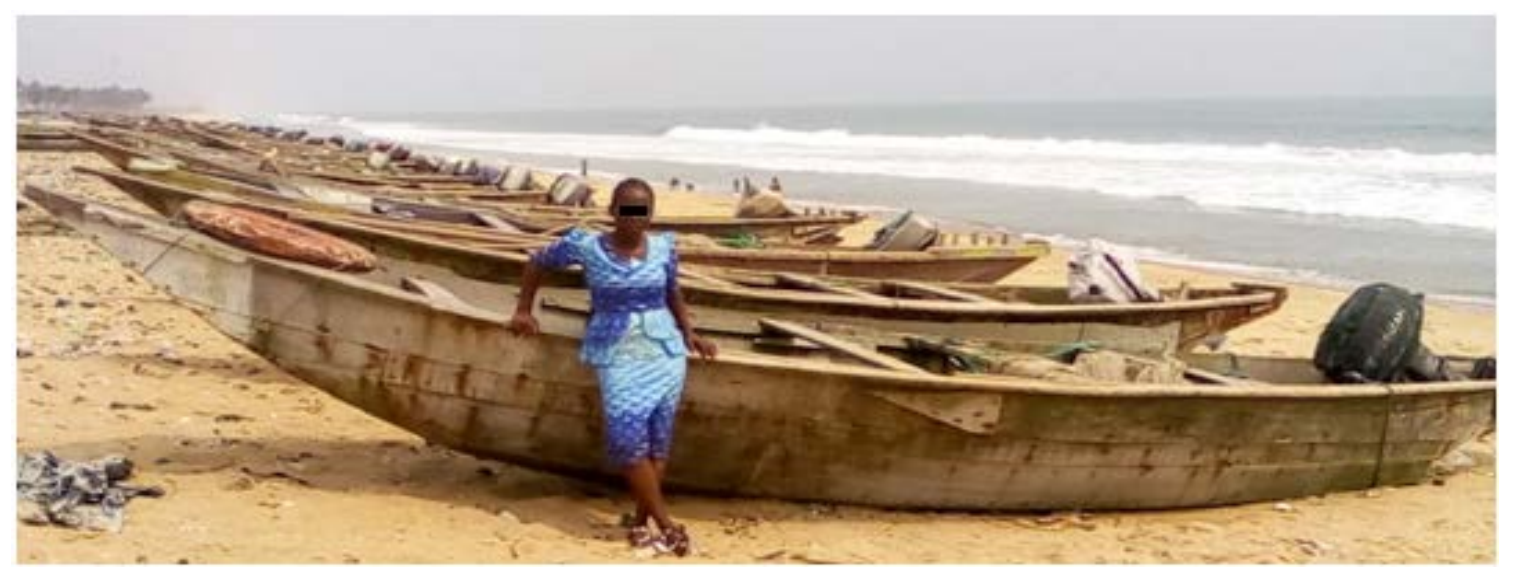

Figure 1. Plank canoes used at the Ilaje Community, Badagry.
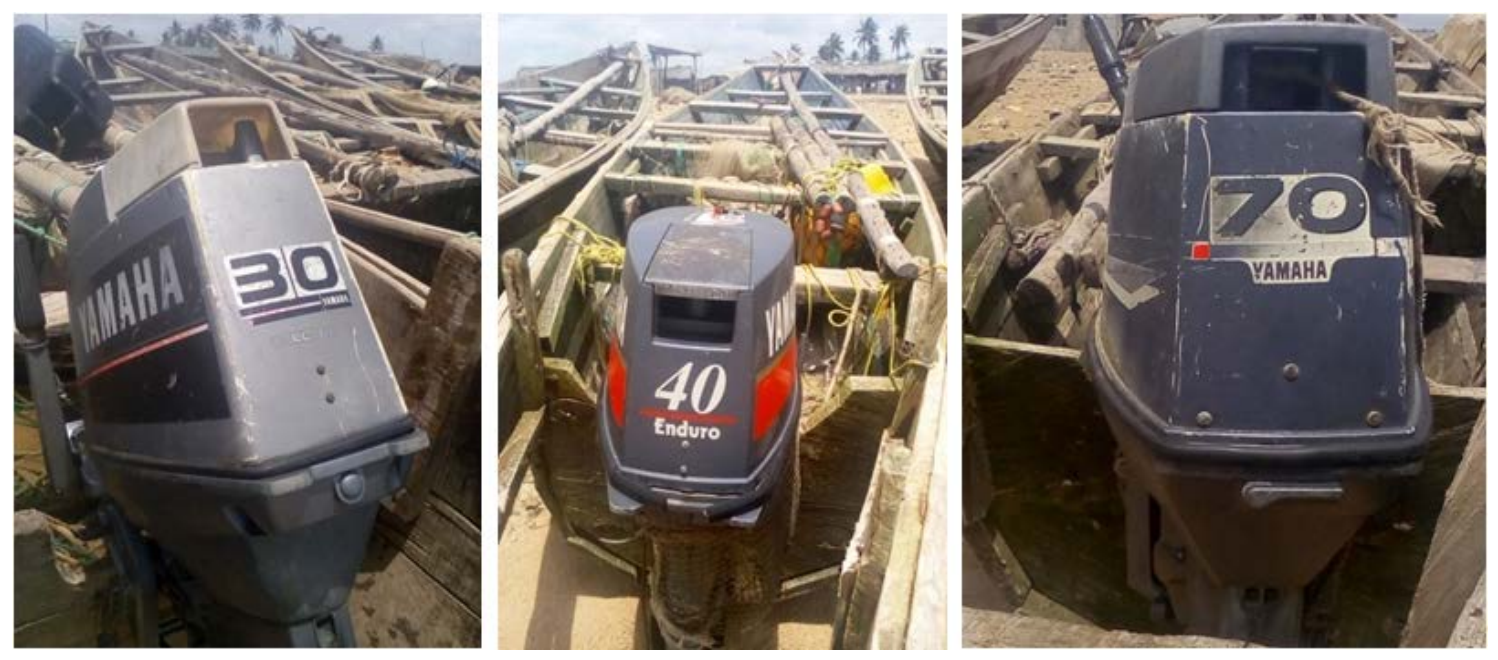

Figure 2. Types of Outboard Engine in use in Ilaje Community, Badagry. 
Twenty-two families of fish were recorded in the fishing community, which were represented by 37 species of fish as shown in Table 2 . The family with the highest number of species was Sciaenidae, which had 5 species (Miracorvina angolensis, Pseudotolithus elongatus, Pseudotolithus senegalensis, Pseudotolithus typus, Pteriscion peli) while 3 species were recorded for Carangidae Family (Chloroscombrus chrysurus, Selene dorsalis, Trachinotus goreensis), and Polynemidae Family (Galeoides decadactylus, Pentanemus quinquarius, Polydactylus quadrifilis). Two species were recorded in Family Clupeidae (Ethmalosa fimbriata, Ilisha africana), Penaeidae (Penaeus monodon, Penaeus notialis), Pomadasyidae (Brachydeuterus auritus, Pomadasys jubelini), Portunidae (Callinectes pallidus, Portunus trituberculatus), Sepiidae (Sepia elegans, Sepia offinalis), respectively. The other families had one species each with Cynoglossus browni, Zanobatus maculatus, Brachydeuterus auritus, Chloroscombrus chrysurus, Pomadasys jubelini, Squilla aculeata calmani, Pseudotolithus typus, Dagetichthys cadenati, Calappa rubroguttata, Portunus trituberculatus) shown in Figure 3.

Table 2. Composition of species recorded in Ilaje Community, in Badagry (July-December, 2017).

\begin{tabular}{|c|c|c|c|}
\hline Family & Fish species & $\begin{array}{c}\text { Common name } \\
\text { (English) }\end{array}$ & $\begin{array}{c}\text { Local name } \\
\text { (Ilaje) }\end{array}$ \\
\hline Octopoteuthidae & Octopus sp & Octopus & Fotanfotan \\
\hline Calappidae & Calappa rubroguttata & Spotted box crab & Akan boju boju \\
\hline \multirow[t]{3}{*}{ Carangidae } & Chloroscombrus chrysurus & Atlantic bumper & Kokote \\
\hline & Selene dorsalis & African lookdown & Aforigboko \\
\hline & Trachinotus goreensis & Longfin pompano & Owere \\
\hline \multirow[t]{2}{*}{ Clupeidae } & Ethmalosa fimbriata & Bonga shad & Folo \\
\hline & Ilisha Africana & West african ilisha & Fanranfanran \\
\hline Cynoglossidae & Cynoglossus browni & Nigerian tonguesole & Abolibo pupa \\
\hline Dasyatidae & Dasyatis margarita & Whiptail stingray & Nate olokuta \\
\hline Drepanidae & Drepane Africana & African sicklefish & Akaraba \\
\hline Palaemonidae & Nematopalaemon hastatus & Estuarine white Shrimp & Ede mefun \\
\hline Heterenchelyidae & Pythonichthys microphthalmus & $\begin{array}{ll}\begin{array}{l}\text { Shorttailed shortfaced } \\
\text { eel }\end{array} & \\
\end{array}$ & Orombo \\
\hline Lutjanidae & Lutjanus agennes & African red snapper & Obira \\
\hline Ophichthidae & Pisodonophis semicinctus & Saddled snake eel & Osan Olokun \\
\hline \multirow{2}{*}{ Penaeidae } & Penaeus monodon & Giant tiger prawn & Ede punch \\
\hline & Penaeus notialis & Southern pink shrimp & Ede ipa \\
\hline \multirow[t]{3}{*}{ Polynemidae } & Galeoides decadactylus & Lesser African threadfin & Opupu \\
\hline & Pentanemus quinquarius & Royal threadfin & Oluroro \\
\hline & Polydactylus quadrifilis & Giant African threadfin & Ofon \\
\hline \multirow[t]{2}{*}{ Pomadasyidae } & Brachydeuterus auritus & Bigeye grunt & Majura \\
\hline & Pomadasys jubelini & Sompat grunt & Ikekere \\
\hline \multirow[t]{2}{*}{ Portunidae } & Callinectes pallidus & Gladiator swimcrab & Akan ori okuta \\
\hline & Portunus trituberculatus & Gazami crab & Ibosi \\
\hline Rajidae & Raja miraletus & Brown ray & Nate \\
\hline \multirow{5}{*}{ Sciaenidae } & Miracorvina angolensis & Angolan croaker & Croaker \\
\hline & Pseudotolithus elongates & Bobo croaker & Awo dudu \\
\hline & Pseudotolithus senegalensis & Law croaker & Croaker \\
\hline & Pseudotolithus typus & Longneck croaker & Apo \\
\hline & Pteroscion peli & Boe drum & Awo \\
\hline \multirow[t]{2}{*}{ Sepiidae } & Sepia elegans & Elegant cuttlefish & Octopus \\
\hline & Sepia offinalis & Common cuttlefish & Octopus \\
\hline
\end{tabular}


Table 2. Cocontinued.

\begin{tabular}{|l|l|l|l|}
\hline \multicolumn{1}{|c|}{ Family } & \multicolumn{1}{c|}{ Fish species } & \multicolumn{1}{c|}{ Common name (English) } & \multicolumn{1}{c|}{ Local name (Ilaje) } \\
\hline Soleidae & Dagetichthys cadenati & Guinean sole & Abolibo dudu \\
\hline Sphyraenidae & Sphyraena gucchando & Guachanche barracuda & Ijakere okun \\
\hline Squilidae & Squilla aculeata calmani & Guinean mantis shrimp & Ede Ipa \\
\hline Tetraodontidae & Lagocephalus laevigatus & Smooth puffer & Obubu \\
\hline Trichuiridae & Trichiurus lepturus & Largehead hairtail & Doje \\
\hline Zanobatidae & Zanobatus maculates & Maculates panray & Nate Oni Sandpaper \\
\hline
\end{tabular}

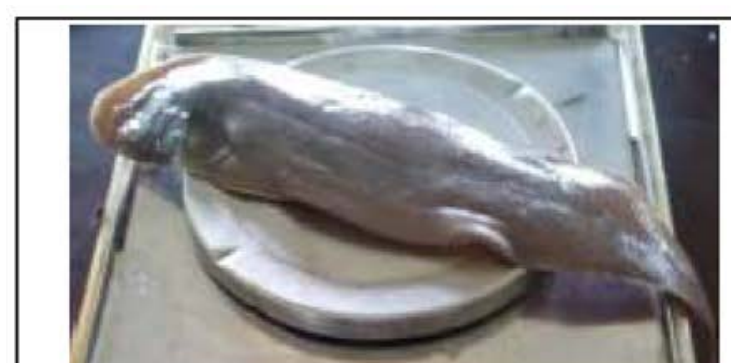

Plate 1. Cynoglossus browni.

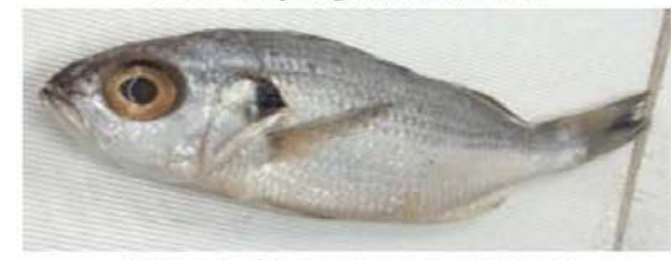

Plate 3. Brachydeuterus auritus.

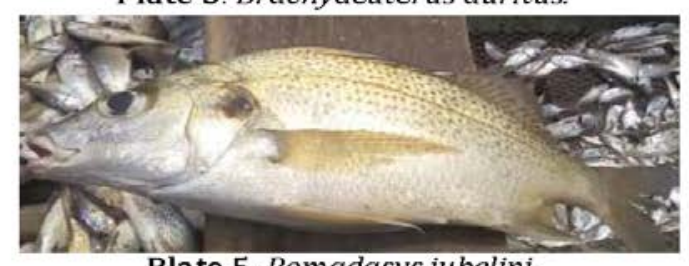

Plate 5. Pomadasys jubelini.

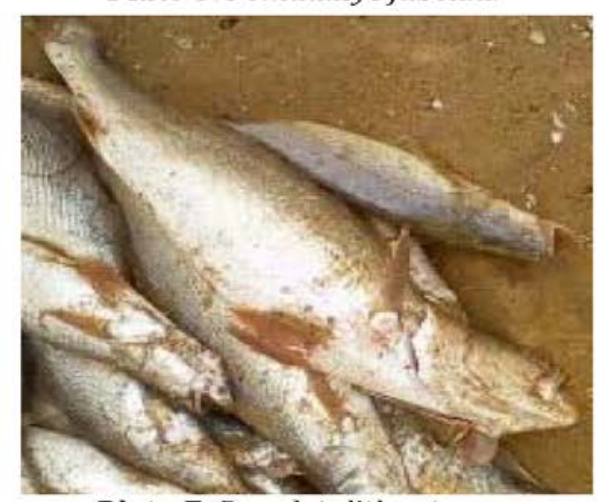

Plate 7. Pseudotolithus typus.

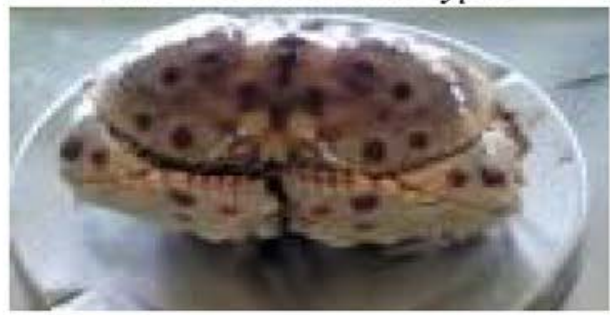

Plate 9. Calappa rubroguttata.

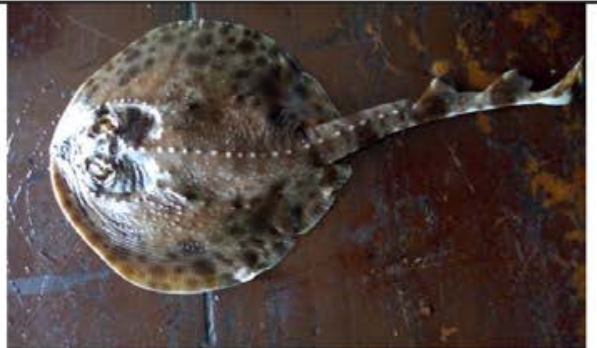

Plate 2. Zanobatus maculates

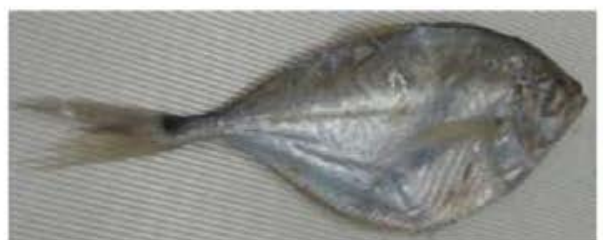

Plate 4. Chloroscombrus chrysurus.

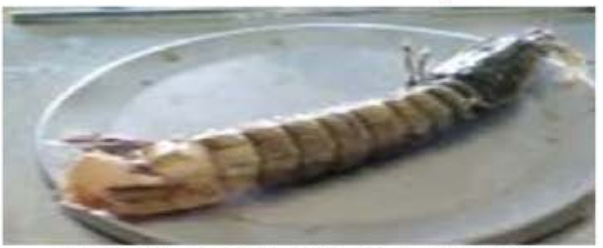

Plate 6. Squilla aculeata calmani.

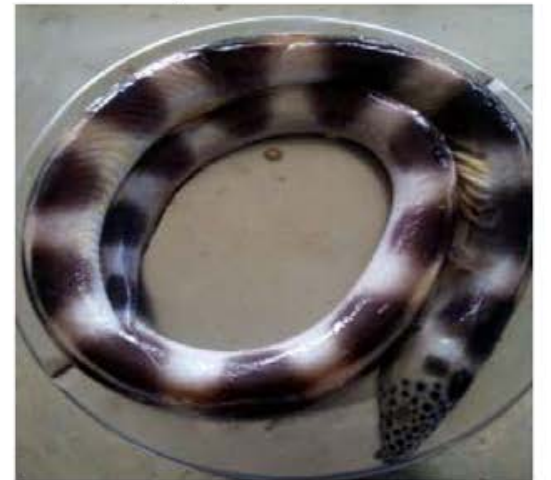

Plate 8. Dagetichthys cadenati.

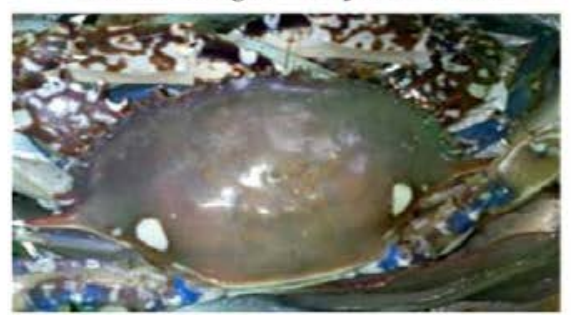

Plate 10. Portunus trituberculatus.

Figure 3. Composition of species recorded in Ilaje Community, in Badagry (July-December, 2017). 
The species, number of specimens, mean length of fish species, mean weight of fish species, allometry value (b), correlation coefficient ( $r$ ), condition factor ' $k$ ', relative condition factor, coefficient of determination $\left(\mathrm{r}^{2}\right)$, standard error and t-test of the fishes obtained during the study are presented in Table 3. The value of the regression coefficient (b) in this study showed that the pattern of growth was negative allometric $(b<3)$ for Drepana africana, Pentanemus quinquarius, Sepia elegans, Penaeus notialis, Raja miraletus, Calappa rubroguttata, Zanobatus maculates, Penaeus monodon, Sphyraena gucchando, Trachinotus goreensis, Pythonichthys microphthalmus, Pisodonophis semicinctus, Octopus $\mathrm{sp}$, Callinectes pallidus, Selene dorsalis, Sepia offinalis, Cynoglossus browni, Dasyatis margarita, Miracovina angolensis, Lutjanus agennes, Lagocephallus laevigatus, Trichiurus lepturus, Squilla aculeata calmani, Ilisha africana, Portunus trituberculatus, Pomadasys jubelini, Chloroscombrus chrysurus, Brachydeuterus auritus, Dagetichthys cadenati and Ethmalosa fimbriata. On the contrary, positive allometric $(\mathrm{b}>3)$ were recorded for Galeoides decadactylus, Pseudotolithus elongatus, Pseudotolithus typus, Pteriscion peli, Pseudotolithus senegalensis, Polydactylus quadrifilis. The values of correlation coefficient (r) varied from -0.264 in Sepia elegans (Sepiidae) to 1.000 in Dasyatis margarita (Dasyatidae). Lowest condition factor $(\mathrm{K})(0.321)$ was recorded in Trichiurus lepturus (Trichiuridae) while the highest value (20.304) was observed in Calappa rubroguttata (Calappidae). The large range might be as a result of species variation and environmental condition.

Table 3. The species, number of specimens, mean length of fish species, mean weight of fish species, allometry value (b), correlation coefficient (r), condition factor ' $k$ ', relative condition factor, coefficient of determination $\left(\mathrm{r}^{2}\right)$, standard error and $\mathrm{t}$-test of the fishes obtained during the study.

\begin{tabular}{|c|c|c|c|c|c|c|c|c|c|c|c|c|}
\hline Fish specie & $\mathbf{N}$ & $\begin{array}{l}\text { \% sp. } \\
\text { comp. }\end{array}$ & $\frac{\text { L }(\mathrm{cm})}{(\text { Mean } \pm \text { S.D) }}$ & $\frac{\text { W (g) }}{(\text { Mean } \pm \text { S.D) }}$ & $\mathbf{k}$ & $\mathbf{R}$ & $\mathbf{a}$ & $\mathbf{b}$ & Kn & $\mathbf{r}^{2}$ & t-test & GT \\
\hline $\begin{array}{l}\text { Brachydeuterus } \\
\text { auritus }\end{array}$ & 20 & 5.45 & $11.80 \pm 2.98$ & $30.02 \pm 21.94$ & 1.58 & 0.9432 & -1.6131 & 2.8127 & 0.55 & 0.9129 & -0.1170 & - \\
\hline $\begin{array}{l}\text { Calappa } \\
\text { rubroguttata }\end{array}$ & 3 & 0.82 & $8.80 \pm 0.06$ & $114.39 \pm 0.70$ & 20.30 & 0.6664 & 1.7190 & 0.4814 & 4.88 & 0.4449 & -0.2087 & - \\
\hline $\begin{array}{l}\text { Callinectes } \\
\text { pallidus }\end{array}$ & 11 & 3.00 & $13.38 \pm 10.40$ & $97.35 \pm 167.53$ & 4.49 & 0.9864 & 0.0285 & 1.6205 & 1.08 & 0.5860 & -0.2581 & - \\
\hline $\begin{array}{l}\text { Chloroscombrus } \\
\text { chrysurus }\end{array}$ & 9 & 2.45 & $15.57 \pm 8.18$ & $57.29 \pm 61.56$ & 1.08 & 0.9588 & -1.6314 & 2.6827 & 0.75 & 0.9435 & -0.1194 & - \\
\hline $\begin{array}{l}\text { Cynoglossus } \\
\text { browni }\end{array}$ & 10 & 2.72 & $22.15 \pm 6.87$ & $160.30 \pm 302.96$ & 1.17 & 0.3411 & -1.4794 & 2.4954 & 1.15 & 0.4944 & -0.0324 & - \\
\hline $\begin{array}{l}\text { Dagetichthys } \\
\text { cadenati }\end{array}$ & 5 & 1.36 & $12.06 \pm 1.93$ & $9.09 \pm 4.64$ & 0.49 & 0.9771 & -2.1572 & 2.8576 & 0.39 & 0.9838 & - & - \\
\hline $\begin{array}{l}\text { Dasyatis } \\
\text { margarita }\end{array}$ & 3 & 0.82 & $33.17 \pm 1.61$ & $325.83 \pm 29.83$ & 0.89 & 0.9995 & -0.3295 & 1.8688 & 1.54 & 0.9993 & -0.0613 & - \\
\hline Drepana africana & 5 & 1.36 & $12.60 \pm 0.55$ & $81.06 \pm 59.60$ & 4.04 & 0.1843 & 3.5462 & $\begin{array}{c}- \\
1.5826 \\
\end{array}$ & 0.19 & 0.0073 & -0.0737 & - \\
\hline $\begin{array}{l}\text { Ethmalosa } \\
\text { fimbriata }\end{array}$ & 3 & 0.82 & $8.67 \pm 0.21$ & $6.17 \pm 0.45$ & 0.95 & 0.9930 & -2.0134 & 2.9887 & 0.23 & 0.9868 & - & I \\
\hline $\begin{array}{l}\text { Galeoides } \\
\text { decadactylus }\end{array}$ & 7 & 1.91 & $12.73 \pm 4.80$ & $43.29 \pm 69.47$ & 1.28 & 0.9725 & -2.1998 & 3.2814 & 0.55 & 0.9930 & 0.0446 & + \\
\hline Ilisha Africana & 29 & 7.90 & $11.09 \pm 2.27$ & $27.50 \pm 57.68$ & 2.13 & 0.0704 & -1.1738 & 2.2088 & 0.53 & 0.2036 & -0.1644 & - \\
\hline $\begin{array}{l}\text { Lagocephallus } \\
\text { laevigatus }\end{array}$ & 4 & 1.09 & $33.13 \pm 39.64$ & $865.50 \pm 991.54$ & 4.02 & 0.8469 & -0.4672 & 2.0863 & 1.22 & 0.9011 & -0.0518 & - \\
\hline Lutjanus agennes & 3 & 0.82 & $27.83 \pm 14.92$ & $714.56 \pm 732.86$ & 3.31 & 0.9992 & -0.0668 & 1.9711 & 1.41 & 0.9996 & -0.0210 & - \\
\hline $\begin{array}{l}\text { Miracovina } \\
\text { angolensis }\end{array}$ & 3 & 0.82 & $13.77 \pm 0.21$ & $27.91 \pm 0.86$ & 1.07 & 0.9371 & -0.7449 & 1.9235 & 0.83 & 0.8743 & -0.2929 & - \\
\hline $\begin{array}{l}\text { Nematopalaemon } \\
\text { hastatus }\end{array}$ & 80 & 21.80 & $3.49 \pm 1.07$ & $4.78 \pm 1.11$ & 17.20 & 0.3650 & 0.5280 & 0.2630 & 3.63 & 0.0860 & 24.0155 & - \\
\hline Octopus species & 3 & 0.82 & $48.20 \pm 1.59$ & $427.08 \pm 20.63$ & 0.38 & 0.9963 & 0.1746 & 1.4591 & 1.65 & 0.9917 & -0.1193 & - \\
\hline
\end{tabular}


Table 3. Continued.

\begin{tabular}{|c|c|c|c|c|c|c|c|c|c|c|c|c|}
\hline Fish specie & $\mathbf{N}$ & $\begin{array}{l}\text { \% sp. } \\
\text { comp. }\end{array}$ & $\frac{\text { L }(\mathrm{cm})}{(\text { Mean } \pm \text { S.D) }}$ & $\frac{\text { W (g) }}{(\text { Mean } \pm \text { S.D) }}$ & $\mathbf{k}$ & $\mathbf{R}$ & $\mathbf{a}$ & $\mathbf{b}$ & Kn & $\mathbf{r}^{2}$ & t-test & $\begin{array}{l}\text { G } \\
T\end{array}$ \\
\hline $\begin{array}{l}\text { Penaeus } \\
\text { monodon }\end{array}$ & 5 & 1.36 & $20.20 \pm 7.69$ & $136.00 \pm 134.47$ & 1.42 & 0.9443 & $\begin{array}{c}- \\
1.0818\end{array}$ & 2.3876 & 1.10 & 0.9570 & $\begin{array}{c}- \\
0.0613\end{array}$ & - \\
\hline Penaeus notialis & 28 & 7.63 & $7.91 \pm 2.84$ & $5.09 \pm 2.31$ & 4.22 & 0.5205 & 0.3914 & 0.3191 & 2.24 & 0.1163 & $\begin{array}{c}- \\
18.282 \\
8\end{array}$ & - \\
\hline $\begin{array}{l}\text { Pentanemus } \\
\text { quinquarius }\end{array}$ & 4 & 1.09 & $20.45 \pm 1.37$ & $56.11 \pm 11.41$ & 0.61 & 0.7915 & 1.5824 & 0.1122 & 9.13 & 0.0882 & $\begin{array}{c}- \\
0.4903\end{array}$ & - \\
\hline $\begin{array}{l}\text { Pisodonophis } \\
\text { semicinctus }\end{array}$ & 3 & 0.82 & $18.20 \pm 0.20$ & $29.61 \pm 0.46$ & 0.49 & 0.9631 & $\begin{array}{c}- \\
0.2459 \\
\end{array}$ & 1.3629 & 1.14 & 0.9276 & $\begin{array}{c}- \\
0.8868\end{array}$ & - \\
\hline $\begin{array}{l}\text { Polydactylus } \\
\text { quadrifilis }\end{array}$ & 4 & 1.09 & $11.98 \pm 0.62$ & $25.09 \pm 11.18$ & 1.41 & 0.8845 & $\begin{array}{c}- \\
7.7043 \\
\end{array}$ & 8.4126 & 0.30 & 0.8364 & 0.4782 & + \\
\hline $\begin{array}{l}\text { Pomadasys } \\
\text { jubelini }\end{array}$ & 4 & 1.09 & $21.58 \pm 0.46$ & $337.70 \pm 28.33$ & 3.36 & 0.6824 & $\begin{array}{c}- \\
0.8953\end{array}$ & 2.5660 & 1.27 & 0.4707 & $\begin{array}{c}- \\
0.0101 \\
\end{array}$ & - \\
\hline $\begin{array}{l}\text { Portunus } \\
\text { trituberculatus }\end{array}$ & 4 & 1.09 & $25.88 \pm 14.12$ & $223.66 \pm 257.80$ & 1.04 & 0.9518 & $\begin{array}{c}- \\
1.2220\end{array}$ & 2.4214 & 1.31 & 0.9992 & $\begin{array}{c}- \\
0.0452\end{array}$ & - \\
\hline $\begin{array}{l}\text { Pseudotolithus } \\
\text { elongates }\end{array}$ & 5 & 1.36 & $14.62 \pm 3.12$ & $30.74 \pm 27.45$ & 0.83 & 0.9870 & $\begin{array}{c}- \\
2.7052\end{array}$ & 3.5327 & 0.61 & 0.9480 & 0.1147 & + \\
\hline $\begin{array}{l}\text { Pseudotolithus } \\
\text { senegalensis }\end{array}$ & 4 & 1.09 & $17.88 \pm 4.44$ & $57.25 \pm 39.08$ & 0.82 & 0.9886 & $\begin{array}{c}- \\
3.1043\end{array}$ & 3.8128 & 0.90 & 0.9941 & 0.1450 & + \\
\hline $\begin{array}{l}\text { Pseudotolithus } \\
\text { typus }\end{array}$ & 25 & 6.81 & $18.75 \pm 7.91$ & $126.17 \pm 199.10$ & 0.93 & 0.9681 & $\begin{array}{c}- \\
2.9709 \\
\end{array}$ & 3.7181 & 1.01 & 0.9249 & 0.1383 & + \\
\hline Pteriscion peli & 10 & 2.72 & $12.30 \pm 1.47$ & $28.33 \pm 13.92$ & 1.42 & 0.9285 & $\begin{array}{c}- \\
2.6973\end{array}$ & 3.7758 & 0.48 & 0.9261 & 0.2536 & + \\
\hline $\begin{array}{l}\text { Pythonichthys } \\
\text { microphthalmus }\end{array}$ & 3 & 0.82 & $19.33 \pm 11.93$ & $81.07 \pm 68.37$ & 1.68 & 0.9947 & 0.1687 & 1.3318 & 1.31 & 0.9744 & $\begin{array}{c}- \\
0.2993 \\
\end{array}$ & - \\
\hline Raja miraletus & 3 & 0.82 & $37.03 \pm 0.25$ & $360.07 \pm 1.16$ & 0.71 & 0.9903 & 1.8185 & 0.4704 & 2.40 & 0.9810 & $\begin{array}{c}- \\
0.5510 \\
\end{array}$ & - \\
\hline Selene dorsalis & 6 & 1.63 & $11.23 \pm 0.32$ & $38.47 \pm 1.98$ & 2.72 & 0.9324 & $\begin{array}{c}- \\
0.2062\end{array}$ & 1.7049 & 0.94 & 0.8610 & $\begin{array}{c}- \\
0.4354 \\
\end{array}$ & - \\
\hline Sepia elegans & 3 & 0.82 & $8.00 \pm 0.50$ & $14.45 \pm 2.65$ & 2.89 & -0.2648 & 1.8389 & -0.7581 & -1.84 & 0.0608 & $\begin{array}{c}- \\
0.7166 \\
\end{array}$ & - \\
\hline Sepia offinalis & 3 & 0.82 & $7.73 \pm 0.21$ & $32.44 \pm 1.79$ & 7.02 & 0.8881 & $\begin{array}{c}- \\
0.0903\end{array}$ & 1.8024 & 0.83 & 0.7955 & 0.1425 & - \\
\hline $\begin{array}{l}\text { Sphyraena } \\
\text { gucchando }\end{array}$ & 3 & 0.82 & $26.40 \pm 0.53$ & $122.44 \pm 2.00$ & 0.67 & 0.8789 & 1.0621 & 0.7216 & 1.99 & 0.7717 & $\begin{array}{c}- \\
0.6136\end{array}$ & - \\
\hline $\begin{array}{l}\text { Squilla aculeata } \\
\text { calmani }\end{array}$ & 3 & 0.82 & $21.00 \pm 9.54$ & $56.10 \pm 55.34$ & 0.56 & 0.9990 & $\begin{array}{c}- \\
1.2350\end{array}$ & 2.2004 & 1.04 & 0.9964 & $\begin{array}{c}- \\
0.1489\end{array}$ & - \\
\hline $\begin{array}{l}\text { Trachinotus } \\
\text { goreensis }\end{array}$ & 4 & 1.09 & $25.75 \pm 9.74$ & $313.00 \pm 277.65$ & 2.98 & -0.0972 & 1.1192 & 0.8894 & 1.85 & 0.1313 & $\begin{array}{c}- \\
0.0869\end{array}$ & - \\
\hline $\begin{array}{l}\text { Trichiurus } \\
\text { lepturus }\end{array}$ & 41 & 11.17 & $13.72 \pm 13.40$ & $14.22 \pm 34.06$ & 0.32 & 0.9338 & $\begin{array}{c}- \\
1.7475\end{array}$ & 2.1789 & 0.39 & 0.8681 & $\begin{array}{c}- \\
3.9204\end{array}$ & - \\
\hline $\begin{array}{l}\text { Zanobatus } \\
\text { maculates }\end{array}$ & 4 & 1.09 & $28.25 \pm 7.37$ & $293.10 \pm 103.99$ & 1.69 & 0.4714 & 1.5579 & 0.6117 & 2.28 & 0.1299 & $\begin{array}{c}- \\
0.2395\end{array}$ & - \\
\hline
\end{tabular}

$\mathrm{N}=$ Sample size; $\%=$ Percentage, S.D. = Standard deviation, $\mathrm{a}$ and $\mathrm{b}=$ regression coefficient; $\mathrm{r}=$ correlation coefficient; $\mathrm{K}=$ condition factor; $\mathrm{L}=$ total length; $\mathrm{W}=$ weight; Growth Type (GT): +: Positive allometric, -: Negative allometric, I: Isometric.

All the women in the study area process their shrimps/fish by smoking. The shrimps were all smoked on a platform (Ihoru) made of bamboo in a smoking house (Figure 4) with length, breadth and depth illustrated in Table 4. However, 42.31\%, 38.46\% and $19.23 \%$ use circular drum, rectangular zinc and mud wall smoking kiln, respectively, for the smoking of fish (Figure 4). One circular smoking kiln will contain four wire gauzes while one wire accommodates 40-50 fishes (Croakers). However, difficulty in terms of timing to dry exists in smoking of Ilisha africana, as it takes about 9-12 h of active smoking before it gets dried. In contrast, cray fish takes little time to smoke to dry, at about 4-5 h without the occurrence of rainfall. 
Table 4. Length, breadth and Depth of Smoking house for shrimp.

\begin{tabular}{|l|l|l|c|l|l|l|l|l|}
\hline \multicolumn{3}{|c|}{ Length (cm) } & \multicolumn{3}{c|}{ Breadth (cm) } & \multicolumn{3}{c|}{ Depth (cm) } \\
\hline Min & Max & Mean \pm S.D & Min & Max & Mean \pm S.D & Min & Max & Mean \pm S.D \\
\hline 914.4 & 1699.2 & $1259.45 \pm 325.08$ & 381 & 406.4 & $392.8 \pm 11.02$ & 114.3 & 127 & $120.3 \pm 5.44$ \\
\hline
\end{tabular}

Min=Minimum, Max=Maximum, S. D=Standard deviation.

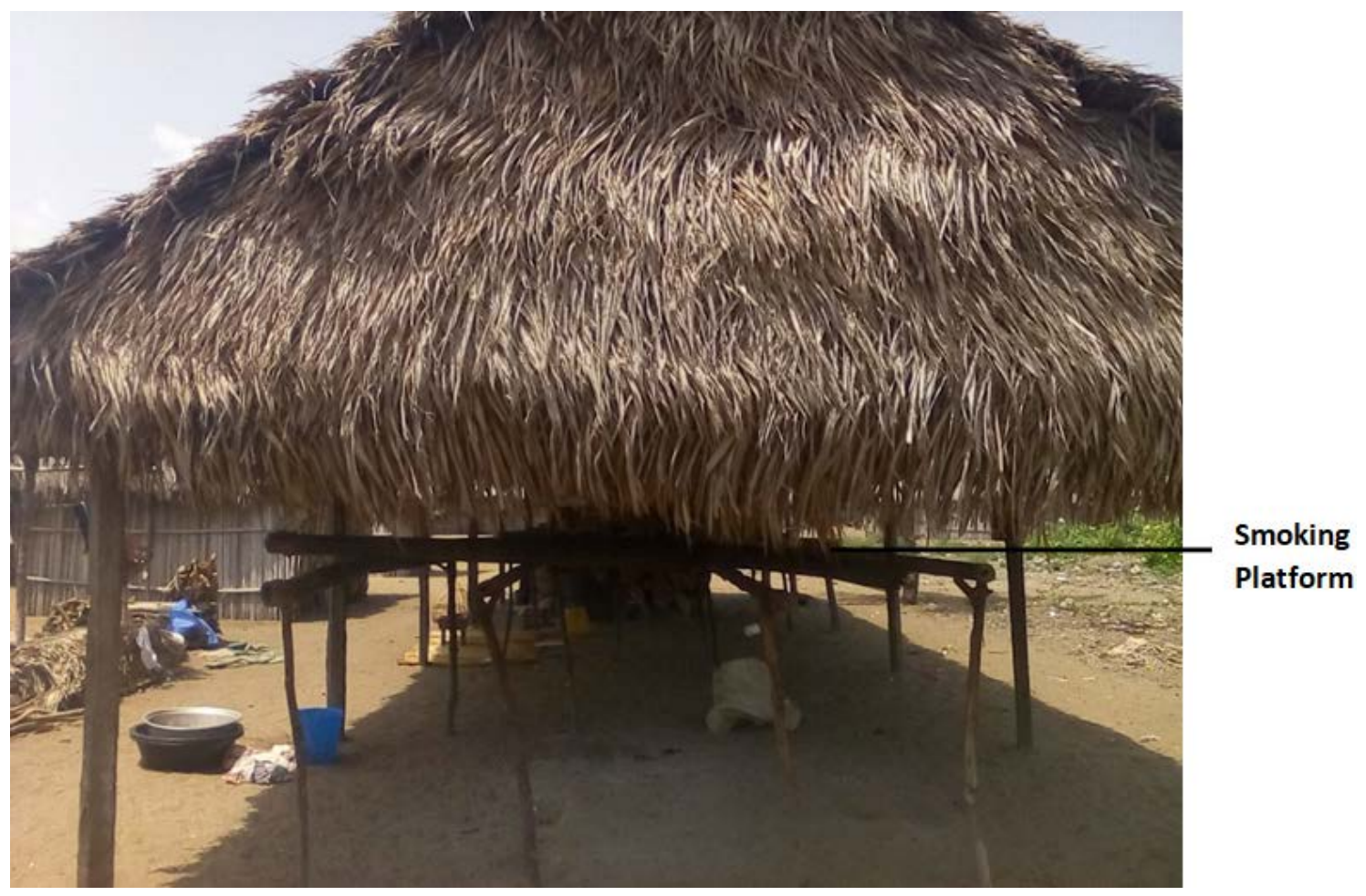

Figure 4. Shrimp smoking house.

The composition of data showed that the economic active age group of the respondents are within 26-36 years $(30.12 \%)$ and $37-47$ years $(25.30 \%)$, meaning that overwhelming majority of fishermen $(55.42 \%)$ fell within the economic active age. While less active group were 15-25 years (15.65\%) and 48-58 years (10.84\%). However, the percentage of male respondent was $73.53 \%$ and female $26.47 \%$. An average of forty canoe carriers 'pilots' (Figure 5) responsible for hauling the Canoe, before and after landing were present in the Community. A minimum of fourteen pilots carries a canoe. 


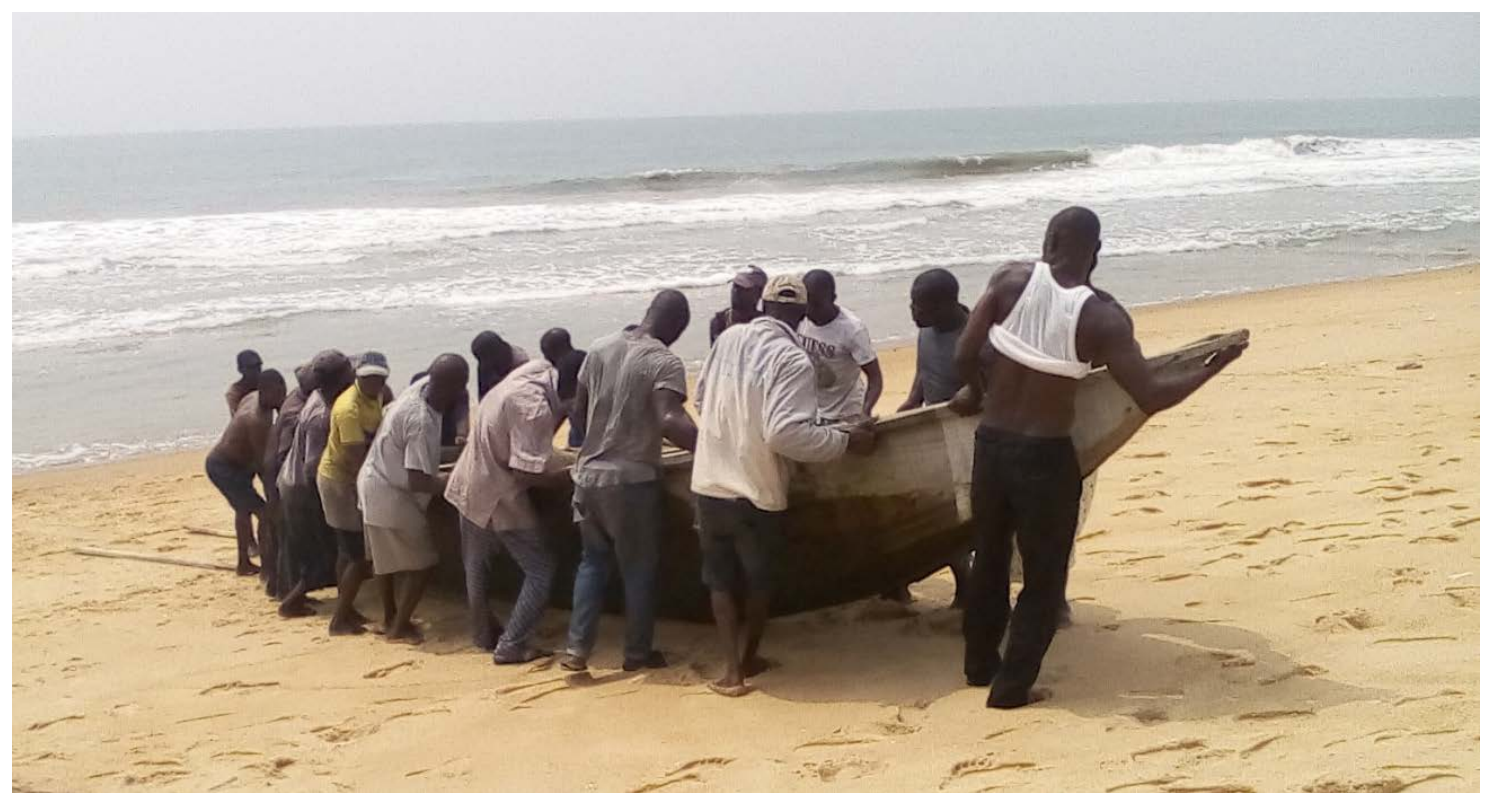

Figure 5. A canoe being manually lifted from the water to the sand beach.

Additionally, varying on schooling and holiday periods, minimum of two and maximum of forty children, within the age of six and fourteen were seen picking bycatches (Figura 6) from the canoes. Also, the study revealed that 5.88\% of respondents had no formal education while $25 \%, 55.9 \%$ and $13.2 \%$ had primary, secondary and tertiary education, respectively. The implication of this finding is that significant percentage of the respondents will be able to read, write or have favourable disposition toward appreciating and conforming to what the provisions of the decree says. $4.41 \%$ of respondent had between 1-5 years shrimping experience while $10.3 \%, 17.6 \%, 27.9 \%$, and $39.7 \%$ had 6-10 years, 11-15years, 16-20 years and 21-25years of shrimping experience respectively as presented in Figure 5. The implication of this finding is that profound majority of respondents had significant years of experience in shrimping. 2.94\%, $4.41 \%$, $2.94 \%$ of respondents had between 1-5 years, 31-40 years, 41-45 years of fishing experience while $11.76 \%, 14.71 \%, 22.06 \%, 26.47 \%$, had $6-10$ years, $11-15$ years, $16-20$ years and 21-25 years of fishing experience, as shown in Figure 6. The implication of this finding is that profound majority of respondents had significant years of experience in fishing, that naturally, should make them develop attitudes and practices responsive to sustainable exploitation of fishery resources. The source of finance embraced by the fishermen is represented in Figure 7. The results showed that $72.1 \%$ of them used personal savings to run the business while $7.35 \%$ and $20.6 \%$ respectively were financed through Cooperatives and family/friend. $80.25 \%$ of respondents solely engaged in fishing without any other form of employment while $17.75 \%$ of respondents had other employment. The implication of this finding is that the fisher folks are confined to fishing. The distribution of the fisher folks according to religion showed that everyone in the fishing community is Christians with identification of three Churches. 

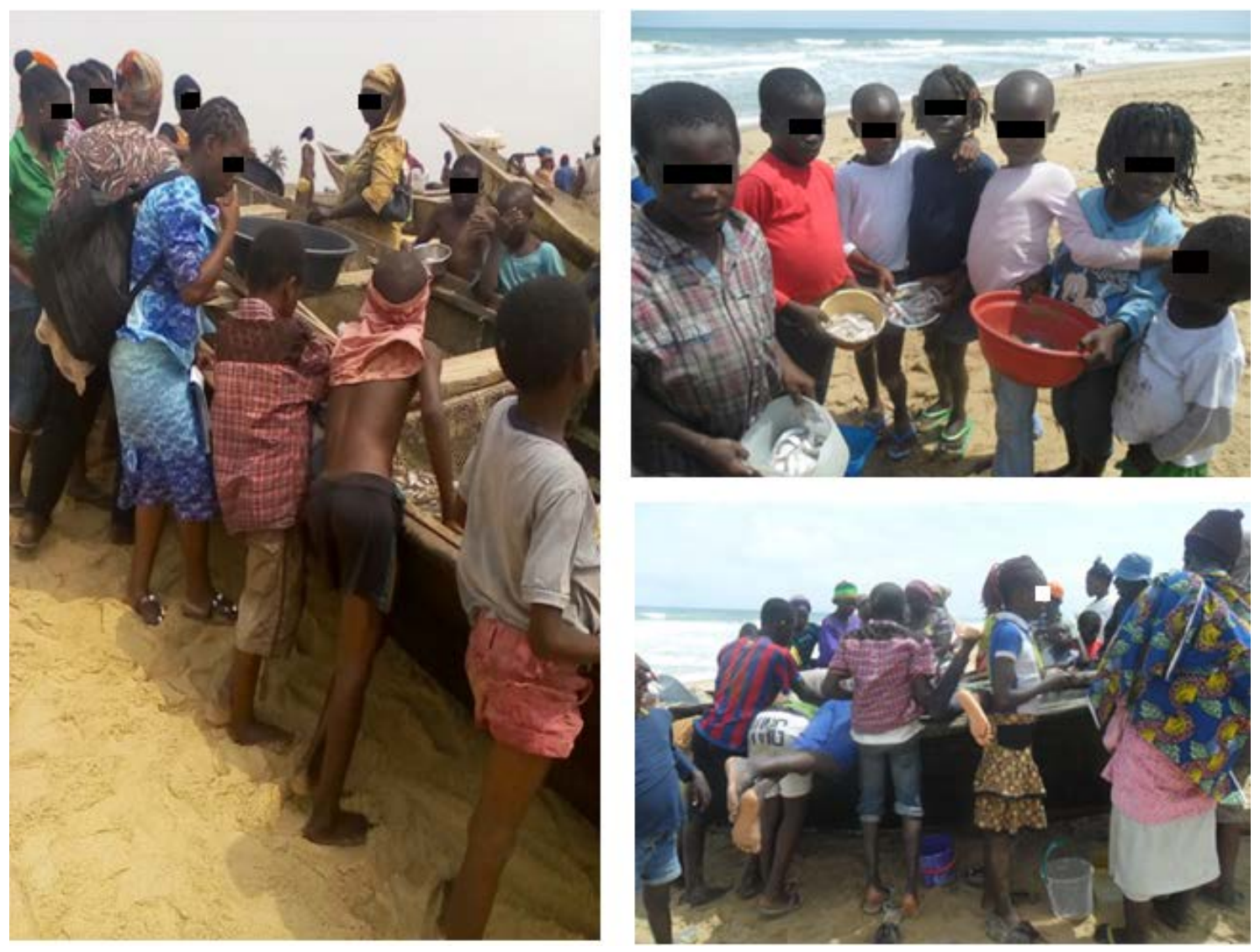

Figure 6. Children picking by-catches.

As stated in Table 5, trawl net and twine (Iro) used in fishing costs between \$194.44-\$200, while the cost of constructing a canoe ranges between $\$ 305.56-\$ 416.67 \mathrm{~A}$ motorized engine with cash at hand costs $\$ 166.67-\$ 4166.67$ but the same type of engine is bought for $\$ 5055.56-\$ 5555.56$ at high purchase, with the horse power of the engine is a sole factor for high price. At the rate of $\$ 0.40$ per litre, 50-120 litres of fuel per canoe varying on the distance covered off shore is being used during fishing for shrimp or fish. $\$ 5.56$ is paid per annum for leasing of land to Landlords, who are documented owners of the land.

Table 5. Cost of fishing/shrimping in the Ilaje Community

\begin{tabular}{|l|l|l|l|}
\hline Fixed cost & Minimum (\$) & Maximum (\$) & Average (\$) \\
\hline Land rent & 5.60 & 5.60 & 5.60 \\
\hline Canoe & 308.00 & 420.00 & 364.00 \\
\hline Motorized engine (normal price) & 1680.00 & 4200.00 & 2940.00 \\
\hline Motorized engine( high purchase) & 3080.00 & 5600.00 & 4200.00 \\
\hline Trawl net and twine & 196.00 & 201.60 & 198.80 \\
\hline Other Accessories & 126.00 & 140.00 & 133.00 \\
\hline Variable Cost & \multicolumn{3}{l|}{} \\
\hline Fuel @ \$145 per litre & 20.30 & 69.02 \\
\hline
\end{tabular}


Shrimp/Crayfish are not measured in grams or kilograms but in 'basins' (Figure 7) with price ranging from $\$ 50$ - $\$ 105.56$ (Table 6). One kampala (Figure 8) is given to fish carries, which is usually sold at $10 \%$ of the actual price of one basin. A minimum of half basin and maximum of five basins of crayfish were captured by each landed canoe. Penaeus monodon is sorted out offshore and sold by sight at $\$ 1.11-\$ 2.78$ each, depending on its size because it is rarely captured. Occasionally, fishermen go to fish using trawl net of bigger mesh size. The by-catches (Figure 9) which majorly contain Trichiurus lepturus, Ilisha africana, and other species are sold per basin while Croakers are sold per kg. The selling price of the by-catches and croakers are shown in Table 7.

Table 6. Selling price of fresh Crayfish per basin.

\begin{tabular}{|l|l|l|l|}
\hline Months & Minimum (\$) & Maximum (\$) & Average (\$) \\
\hline July & 70.00 & 98.00 & 84.00 \\
\hline August & 50.40 & 84.00 & 67.20 \\
\hline September & 56.00 & 64.40 & 60.20 \\
\hline October & 58.80 & 70.00 & 64.40 \\
\hline November & 61.60 & 78.40 & 70.00 \\
\hline December & 61.60 & 106.40 & 84.00 \\
\hline
\end{tabular}
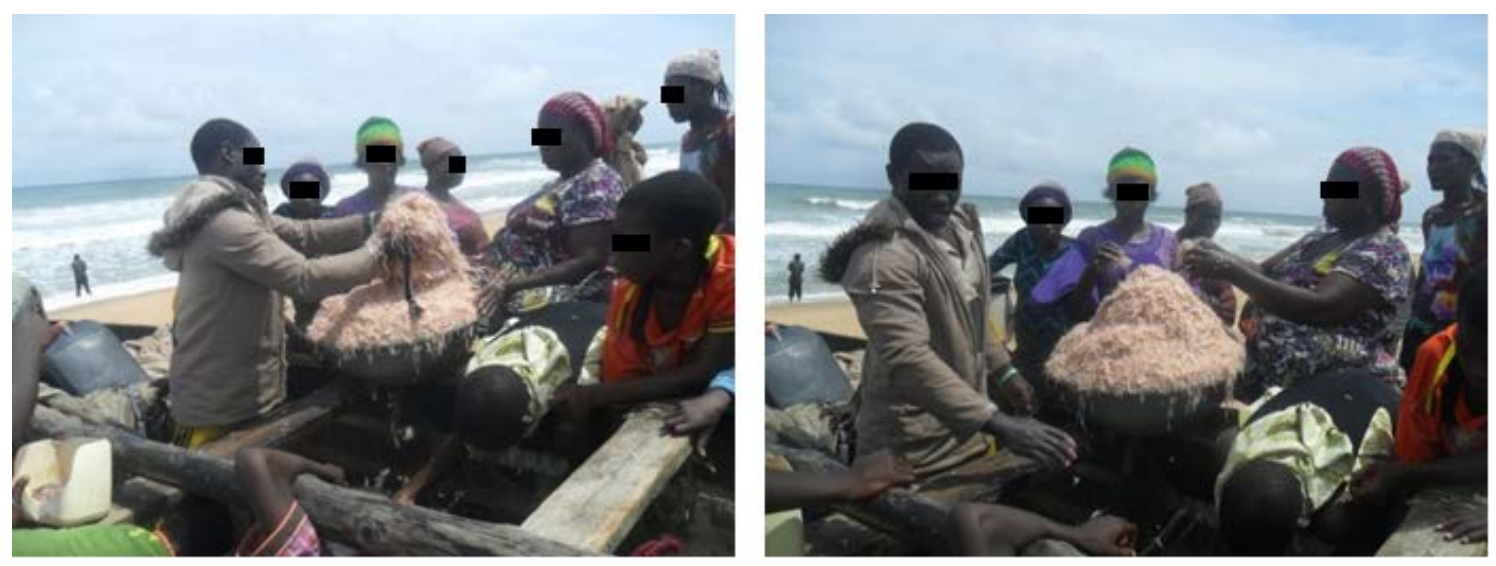

Figure 7. Measurement of crayfish in basins.

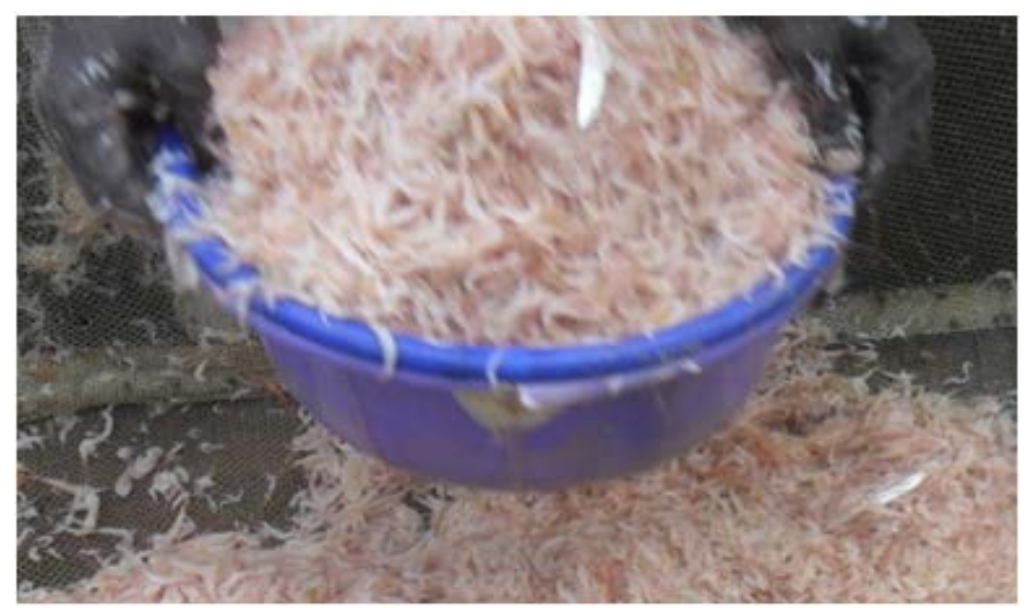

Figure 8. One Kampala of crayfish given to canoe carriers. 


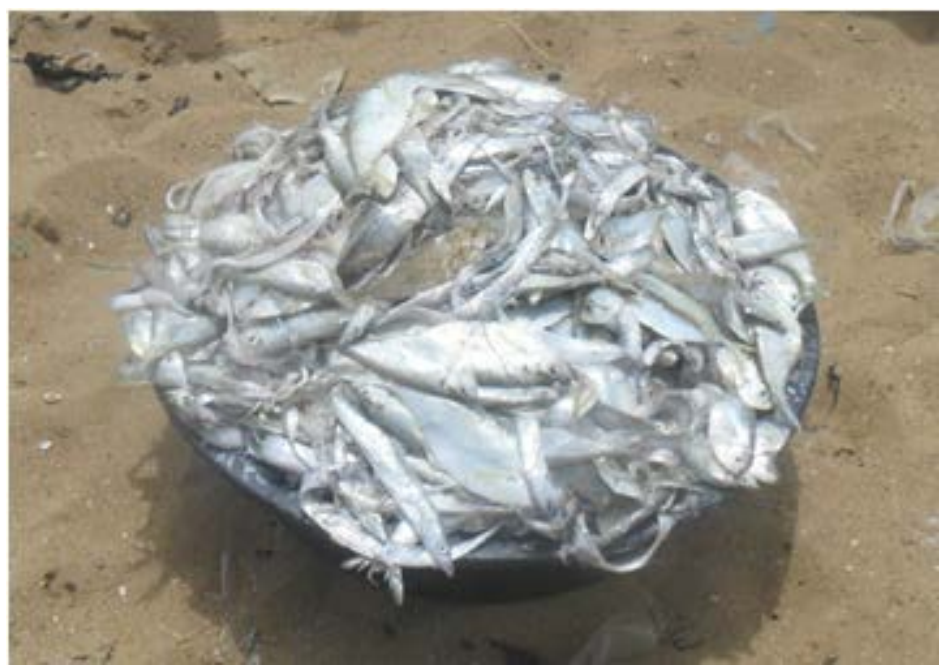

Figure 9. A basin of bycatches canoe carriers.

Table 7. Selling price of by-catches and croakers per basin from fishermen.

\begin{tabular}{|l|l|l|l|l|l|l|}
\hline \multirow{2}{*}{ Monthz } & \multicolumn{3}{|c|}{ By-catch per basin (\$) } & \multicolumn{3}{c|}{ Croakers per kg (\$) } \\
\cline { 2 - 7 } & Minimum & Maximum & Average & Minimum & Maximum & Average \\
\hline July & 25.2 & 28 & 26.6 & 26.6 & 2.8 & 14.7 \\
\hline August & 22.4 & 23.8 & 23.1 & 25.2 & 2.8 & 14 \\
\hline September & 19.6 & 22.4 & 21 & 2.38 & 2.52 & 2.45 \\
\hline October & 18.2 & 19.6 & 18.9 & 2.1 & 2.24 & 2.17 \\
\hline November & 16.8 & 19.6 & 18.2 & 1.68 & 1.96 & 1.82 \\
\hline December & 15.4 & 16.8 & 16.1 & 1.68 & 1.96 & 1.82 \\
\hline
\end{tabular}

\section{Discussion}

The length of the plank canoes used in exploiting the fish from the wild, ranged from $6.1 \mathrm{~m}$ to $6.5 \mathrm{~m}$ and make use of $40-70$ horse power outboard engines. The size of the length and bread of the Canoes is the basis for the use of high powered outboard engines. All the fishermen make use of motorized plank canoe in this study. This varies with that reported by (Olaoye et al., 2012) that most of the respondents made use of boats.

Nigeria coastal zone is home to some 104 species of fish belonging to 50 families (Sikoki, 2013), however 22 families of fish were recorded in Ilaje community, which were represented by 36 species of fish. The decline in fish catches may be due to increase in fishing pressure. Fisheries resources are on the decline in Nigeria due to over exploitation and inadequate management of her coastal waters. For sustainability of these resources, an adequate knowledge of species composition, diversity and relative abundance of her water bodies must be understood and vigorously, pursued (Lawson, 2010). The most predominant fish family in terms of number was Scianidae, this was also recorded by Bolarinwa and Popoola (2014).

The b value estimated for Brachydeuterus auritus in this study was 2.8127 which is similar to $b=2.98$ recorded by Kouadio et al. (2015). Also, both male and female B. auritus reported earlier by Adebiyi (2013), off Lagos coast had negative allometric growth $(b=2.6829)$. The negative allometric growth of Drepana africana recorded in the study showed that the rate of increase in body length is not proportional to the rate of increase 
in body weight. Similar result has been reported by Fafioye and Oluajo (2005). Ethmalosa fimbriata $(b=2.9887)$, obtained in this study showed negative allometric growth or approximately isometric growth, is in contrast to that obtained by Fafioye and Oluajo (2005) and Torres (1991). Negative allometric growth of Pomadasys jubelini $(b=2.566)$ reported in this study was also similar to that reported in Lagos Coast by Adebiyi (2013) and in Badagry Creek by Agboola and Anetekhai (2008). In contrast, positive allometric growth was reported for P. jubelini from the Ivory Coast (Konan et al., 2007) and in Ibeshe Waterside, Lagos Lagoon, Nigeria (Bolarinwa and Popoola, 2014). Polydactylus quadrifilis in this study showed positive allometric growth pattern $(b=8.4126)$ which is in contrast to that reported by Bolarinwa and Popoola (2014). A high positive correlation $(+0.847)$ was recorded in this study, and this was close to that reported by Bolarinwa and Popoola (2014). The condition factor obtained in this study for B. auritus was in line with that obtained by Adebiyi (2013). The mean value of condition factor recorded for P. jubelini (3.360 \pm 0.20$)$ in this study was higher than that recorded by Adebiyi (2013). The values of ' $b$ ' in fish are affected by several factors such as season, habitat, gonad maturity, sex, diet, stomach fullness, health, preservation techniques and annual differences in environmental condition (Le Cren, 1951). Others include seasonal variability of the environment and food availability sample size and the length interval within different areas (Morey et al., 2003) or habitat suitability (Nieto-Navarro et al., 2010). In addition, growth increment, differences in age and stage of maturity as well as environmental conditions such as temperature, salinity and seasonality can affect the value of $b$ for the same species (Weatherley et al., 1987). The coefficient of determination $\left(\mathrm{r}^{2}\right)$ values of the LWRs was positive and highly correlated with $\mathrm{r}^{2}>0.007$ between fish total length and body weight measurements. The least, $\mathrm{r}^{2}=0.007$ was exhibited by Drepana africana and the highest value of $r^{2}=1.00$ by Lutjanus agennes. These imply that species' lengths and weights were growing proportionately. The LWR parameters may be affected by age, maturity (Dulčić and Kraljević, 1995) feeding, reproduction and fishing activities (Bayhan et al., 2008) environmental changes, individual metabolism, sexual maturity and age (Franco-Lopez et al., 2010)

The processors prefer to smoke their shrimps platform ihoru made of bamboo in a smoking house due to the fact that it provides opportunity to evenly spreading the shrimp, which put them in position of absorbing equivalent source of energy to dry. The circular drum had the highest use. It is believed that it allows easy arrangement of fishes and larger number of fishes can be placed on it than other types of smoking. During the period of high catch and landing, all traditional methods of preservation and processing methods employed are not highly efficient in terms of work per unit time leading high post-harvest losses. In order to achieve effective and efficient management practices that could reduce postharvest fish losses, Bolorunduro et al. (2005) implored that mechanized forms of improving the handling and processing methods. From group discussion, about sixty-five women go into processing of shrimp/fish in the community. At the processing ground, women lead fish processing with assistance from family members and hired (female) labourers 'Alagbayan'. None of the fish smokers were men. Major buyers of the smoked crayfish are the igbos and few being Yorubas. Though research was July-December, the fishermen explained that the peak period of high landing of crayfish is April.

Majority of respondents fell within the economic active age. This finding is in agreement with that found out by of Olaoye et al. (2012), stating that most people engaged in fish catching were still active and physically fit. Adeleke (2013) reported that most of the fisher folks were within the economically active age of the population and therefore, constitute a good labour force in fish production, since efforts are being made to increase fish production from the artisanal sector by the Federal Government of Nigeria in recent years. Significant percentage of the respondents went to secondary school, therefore will be able to read and write. Kigbu (2014) also revealed that some of the fisher folks believed 
that additional qualification may not be necessary because fishing is their way of life and the skill for fishing were acquired through their forefathers. Though majority of the fisher folks do not possess post-secondary qualification, they readily accept technological research and technology to ease their fishing process and avoid fishing hazards. In contrast to this study, Adeleke (2013) also stated that 'to the fisher folks, fishing does not require serious training since they are introduced to it right from childhood'.

Active years of experience (21-25 years and 16-20 years) reported in this correlates in which that reported by Kigbu (2014) that reported that $60.6 \%$ has $15-29$ years of experience. This signifies a considerable level of experience in fishing and shrimping. It is believed that this would enhance their efficiency. This finding is in line with Schumpeterian theory of economic development which suggests that technical efficiency is influenced by technical knowledge and understanding in addition to other socio-economic environment with which the fisher folks must take decision (Kalirajan, 1990). Normally, the more the fishing experience, the higher the fish catch level since experience aids fishermen's the performance and fortune (Olomola, 1991).

In this study, the major source of finance is through personal/family finance. Mostly, the women serve as back bone for the fisheries of the community funding of fishing trips, pay for maintenance and repairs of Canoe and other fishing gears. With the shortfall of Credit facilities, loans and support of governmental and nongovernmental organizations, sustainability on the fishing business has been quite difficult. This was supported by Clark et al. (2005) stated that the non-availability of a credit scheme taking into full consideration the peculiar circumstances of small-scale fisheries militate against capital-intensive expansion.

The dominance of respondent who solely engaged in fishing without any other form of employment implies high confinement to fishing. This finding is in agreement with studies by Mathew (2003), he reported that fisher folks are confined to fishing because of lack of tangible employment opportunities in the coastal communities and that this has led in overfishing and its consequent depletion of stocks. Olaoye et al. (2012) also supported stating that fisher folks were involved in one or two other income generating activities that supplement their income, which as a result of the fact that fishery activities alone were not sufficient to meet their family financial obligations. The consequences of being confined to fishing. After fishing, some men buy large or not often caught species of fish at the shore and sell them to star restaurants and hotels.

As a result of the fact that the members of the whole fishing community are Christians, no one goes for fishing/shrimping on Sundays. This result may be as a result of the early missionaries who travelled to countries via water and they might have been the first to penetrate the coastal areas with their Christian religion and this justify the reasons while there are more Christians in the Southern part of Ondo State (Adeleke, 2013) where the Ilajes originally migrated from.

The population of the males outstands that of females, though females also participated actively in fisheries of the community. (Basavakumar, 2011) also reported that male population constituted a higher percentage than the female population. Seijo (1998) stated that in fishing practices, both male and female are engage in capture fisheries. According to Seijo (1998), women are rarely involved in fish capture at sea or on lakes because it inherent dangers, long period of fishing voyage and their dominant role in household activities. Adeleke (2013) supported the finding in this study, stating that fishing activities absorb more males than females because of the strength, quality time required and various risks due to drudgery nature of the fishing job. Marketing has been defined as all processes involved from the production of a commodity until it gets to the final consumer (Crammer, 2001). These processes make the preferred fish species available to the consumer at the right place, price and time. The bulk of work that makes fish get to the final consumers is handled by women. Adebayo and Pitan (2003) supported 
this stating that a greater percentage of women (64.2\%) are actively involved in fish marketing.

Fishing has been erroneously thought to be mainly a male's world, however, in Ilaje Community; there is a symbiotic relationship between the roles of men and women. Mostly, men fish but marketing, processing and preservation that makes fish get to the final consumers is handled by women, as equally reported by Shettima (2014); due to the harsh ecological and physical conditions of the coastal waters making fishing in the wild a male dominated activity. However, the roles are more complex.

While fishing, the men form a crew of fishermen with a Captain (Asiwaju/Olori). When a canoe reaches the shore, the catch is divided into ifo (shares of fish). The income from the catch is divided into three parts (Ifo meta), two parts for the owner of the canoe, although this may split up further if different individuals own the Canoe, motor, and nets. The remaining one part is shared into equally amongst the crew that went for fishing, including the canoe owner if he is part of the crew.

One kampala (Figure 9) bowl which contains the main species of fish/shrimp captured is given to the Canoe carriers 'pilot'. This is sold at a particular price usually $10 \%$ of the price of a basin of the same species. The income derived is divided into three by the elders amongst the Canoe carriers, one portion each for the upkeep of the Community, for the Chairman and the Canoe carriers. Tradition and myths exclude women from going to sea to fish; women are known to have deep fear of the waves of the ocean, while going on and out of the sea.

In this Ilaje Community, when the fishermen do not go for fishing, they mend fishing nets nearby the fish landing site, do extra jobs asides fishing, and meet at joints within the community where the take drinks, smoke and have group discussion. As a result of no fish landing, some women go to buy brackish water fish species especially Chrysichthys nigrodigitatus, from landing site, Badagry market and other nearby market which is then smoked and sold.

Both men and women usually start their fisheries careers (fishing, shrimping, marketing or processing) as helpers or labourers, working for their father, uncle, mother, aunt, or sometimes someone outside their family. Those who can save a small capital from their labour/ help works or access credit can buy their own processing equipment, finance fishing trips and or buy their own fishing gears and craft. However, the capability of women to obtain and sell fish is dependent on their ability to invest in the fishing business of a fishermen or getting fish from a husband/son and therefore achieve the position of the sole buyer/distributing agent of his fish.

The price of the fish is set by queen fishmonger alongside general cooperation of the women; they communicate the price one on one to themselves. The price of the fish varies day by day depending on the catch per unit effort and the cost of fuel used during fishing. The chief fisherman 'Chairman' is the head of the fishing community with good mediation skills and influence in the fishing Community. He is chosen into position by mutual agreement of all the fishermen and is in charge of the management of the beach and landing site, collaborates with local chiefs, external community leaders, Local, State and Federal Government officials. The Chairman is delegated to make sure that local norms are of the community is followed.

Fishermen sell or give their catch to their wives, provided that the wife is a fish monger or / but if an external partner financed the fishing trip, they might be compelled to sell the fish to that person instead. Fishermen give their catches to their wives, if married or mother, if they are not married because the women are to use the profit from fish sales as feeding and house maintenance allowance. Husbands and wives have divided economies in general, and few fishermen are paying for family requirements and college charges. Husbands and wives, however, often function as loan sources for each other. The connection of mutual credit makes marriage essential to both males and women's capacity 
to make a living from fishing. Biological kids are involved in the company as a means of training them to take over from the adults in the future.

In Ilaje Community, Badagry, it is usually considered as beneficial that children participate in job that does not influence their health and personal development or interfere with their education. They collect tiny by-catches from the Canoe on the landing site during holidays and weekends and sell to shore buyers to gain pocket money, help carry the biggest catch home, which a fisherman will never sell except for his household's consumption) and also assist his mom in fish processing. These activities contribute to the growth of children and their families ' well-being; they provide them with abilities and knowledge, and they assist prepare them during their adult lives to be productive members of society. However, some parents don't want their kids to go fishing, so they're limited to going to the coast during catch landing, generally to deter their kids from fishing.

Child labour is work that children should not be doing because: they are too young to work, or - if they are old enough to work - because it is dangerous or otherwise unsuitable for them, it is work that deprives children of their childhood, their potential and their dignity, and that is harmful to their physical and mental development, it is work that interferes with their schooling, takes away their opportunity to attend school, obliges them to leave school pre-maturely, or requires them to attempt to combine school attendance with excessively long and heavy work (ILO, 2017). ILO (2017) also estimated that agriculture (including farming, fishing, aquaculture, forestry, and livestock) is the largest employer of child labour in Africa. Both boys and girls are involved in the fishing industry.

The children are involved in several operations, such as bailing water from canoes, carrying anchors, mending networks, and post-harvesting fish marketing with no sexual exploitation/assault, rape, or usual use of kids. Girls assist their mothers and aunts with easy processing and sales duties, including cleaning, scaling and fishing on platforms for processing.

Although Child's Right Act (Nigeria, 2015) states that 'no child shall be employed to work in any capacity except where he is employed by a member of his family on light work of an agricultural, horticultural or domestic character' boys from age of 15 above sometimes become crew members on fishing canoes. The children in essence become apprentices by assisting their parents and families, learning the trade as they grow up. Children attend school and assist after college and during college holidays with multiple duties.

Ilajes practices patrilineal inheritance, which means that when a fisherman dies, his fishing gears and crafts and other properties are transmitted to his children. However, some of the inheritance could be transferred to a supportive relative or nephew living with the fisherman.

Men control fisheries inputs, and decisions about when, where, and how to fish while the women control and make decisions regarding post-harvest activities such as where to sell, how to market, how to process and so on. Some women own fishing canoe(s), however, so they can exercise control over inputs. In the fisheries industry, canoe owners have important impact as they can dictate when and where a canoe fishes. The proprietor of the Canoe will also decide who the ship should be captained and crewed. Women are a minority of owners of canoes. In agreement with Torell et al. (2015), these women have the potential to have significant influence, at least when it comes to the operation of their own vessels.

Women who inherit or can purchase canoes often allow the Canoes to be operated by their husbands or male parents. When that occurs, the male operator of the canoe is probably the individual who makes most choices about where to fish and what equipment to use. Key females, however, decide to employ foreigners to operate the Canoes. The

Braz. J. Biol. Sci., 2020, Vol. 7, No. 17, p. 261-282. 
reason is that the control of male family members is harder. Outside hires are more likely to follow the Canoe owner's orders.

Women regulate all fishery revenue because they are responsible for covering all domestic expenses, including placing food on the table and taking care of the demands of children.

However, according to Britwum (2009) selling fish does not give women control over the income. Rather, the amount a woman gets is dependent on her husband's discretion. It is clear that husbands and wives are economically dependent on each other, and a large portion of the return from fish sales is turned back into fisheries inputs such as fuel and fishing equipment.

Canoe owners are organized into groups and cooperatives created to organize the payment of land rent ( $\$ 5.56$ per annum) to their landowners who own the property they occupy in order to guarantee the efficient welfare of the Head Fisherman and the fishing community as a whole. Membership helps to boost the bargaining power when buying machinery, as the group can demand a better price than when a person sells on their own. Historically, female processors and marketers were organized into associations and groups but later dissolved due to discrepancies in the handling of association dues.

The Ilaje Community has been in existence for 18 years. The community lack basic social infrastructures. There are no nurseries, primary or secondary schools, pipe burn water, electricity hospital/health centre nor access roads for vehicles. Due to absence of excellent quality and amount of safety equipment, cases of fishermen drowning owing to elevated and rapid sea current or accidents induced by benthos fish harvesting have occurred. The months of May, June and July fall within the danger periods in which fishermen are reported drowning and missing their nets. Though a good swimming skill might be an advantage, it is not an automatic qualification for safety in the sea, especially during turbulent wind with huge waves and fast flowing water current (Ehinmore, 1998).

The land occupied by the fishermen is owned by Chief Jegede and Chief Mobil (Badagry Chiefs) whom fishermen pay land rent per annum. The Ilaje men in the community were said to have married the Eguns, Delta and Ilaje women due to the common occupation of fishing amongst the fishing communities. Majority of the fishermen smoke, giving cognate reasons that the cold from the ocean make them smoke, and therefore increases their body temperature. At the shore, women from within and outside the community sells doughnut, fish roll, purewater, bread and butter and so on.

In this study, the cost of 40-70 horse power outboard engine (both fairly used and new) ranged between $\$ 1666.67$ and $\$ 4166.67$. In contrast, Clark et al. (2005) and Akanni (2008) affirmed that an average outboard engine with 55-65 horse power costs between $\$ 694.44$ to $\$ 1666.67$ depending on the make and state of the engine. The difference in the prices could be due to the current USD exchange rate/value, high cost of importation and inflation. There are very high average costs of fishing instruments, such as outboard motors, canoes, nets and so on needed to set up fishing company. This has led in personal problems in the Fishermen's establishment of craft fishing company, which has likely resulted in the high price of marine fish species. The most expensive of these production factors is apparently an outboard engine that is similarly costly.

\section{Conclusion}

Shrimping is the most profitable form of artisanal fishing and has high contribution to sustainability of financial state of the Fishermen. Output of analyses of length and weight measurement of some species, which were landed in Ilaje Community, Badagry, Lagos State, Nigeria which have not been reported, are available for referrer for further studies. Generally, most of the fish species are being overfished as derived from numerical number and length-weight relationship of species. Sustainable fishing practices 
such as recommended trawl net mesh size should be emphasized in order to reduce overexploitation.

Socioeconomic status of the fisherfolks in Ilaje Community, Badagry is concluded to be average/low, therefore Government and Non-Governmental Organisations (NGOs) should provide infrastructural needs, engage in partnership with them, encourage them to form cooperative societies that will assist them to procure technological advanced fishing gears that would improve their productivity and grant support in terms of improved way of post-harvest processing and preservation, marketing and distribution, thus wastage is minimized and profit is maximized.

\section{Acknowledgement}

Thanks to the fishermen in Ilaje Community, especially Mr. Omowale Akingbemi, Mr. Bonema Titiola, Mr. and Mrs. Adebanjo Eyekole, for granting permission to take and publish photographs, and for their assistance in identifying the local names, and being available for group and individual interview and discussion.

\section{Conflict of interest}

The authors declare that they do not have any conflict of interest.

\section{References}

Adebayo, 0.; Pitan, 0. 0. The role of women in marketing of frozen fish in Lagos State of Nigeria. Proceeding of the 16th Annual Conference of the Fisheries Society of Nigeria (FISON), 2001, Maiduguri, Nigeria, 2003.

Adebiyi, F. A. Growth pattern of the big eye grunt Brachydeuterus auritus (Valenciennes, 1832) off Lagos, Nigeria. Indian Journal of Fisheries, v. 60, no. 3, p. 9-12, 2013.

Adebiyi, F. A. Length-frequency distribution, length-weight relationship and condition factor of sompat grunt Pomadasys jubelini (Cuvier, 1830) off Lagos Coast, Nigeria. Pertanika Journal of Tropical Agricultural Science, v. 36, no. 4, p. 337-344, 2013.

Adeleke, M. L. The socio-economic characteristics of artisanal fisherfolks in the coastal region of Ondo state Nigeria. Journal of Economics and Sustainable Development, v. 4, no. 2, p. 133-139, 2013.

Agboola, J. I.; Anetekhai, M. A. Length-weight relationships of some fresh and brackish water fishes in Badagry Creek, Nigeria. Journal of Applied Ichthyology, v. 24, no. 5, p. 623-625, 2008. https://doi.org/10.1111/j.1439-0426.2008.01079.x

Akanni, K. A. Catch levels and capital investment of artisanal fishermen in Lagos State, Nigeria. Turkish Journal of Fisheries and Aquatic Sciences, v. 8, no. 2, p. 361-368, 2008.

Basavakumar, K. V.; Devendrappa, S.; Srenivas, S. T. A study on profile of fishing community of a village in Karnataka. Karnataka Journal of Agricultural Science, v. 24, no. 5, p. 684-687, 2011.

Bayhan, B.; Sever, T. M.; Taşkavak, E. Length-weight relationships of seven flatfishes (Pisces: Pleuronectiformes) from Aegean Sea. Turkish Journal of Fisheries and Aquatic Sciences, v. 8, no. 2, p. 377-379, 2008.

Bolarinwa, J. B.; Popoola, Q. Length-weight relationships of some economic fishes of Ibeshe waterside, Lagos lagoon, Nigeria. Journal of Aquaculture Research \& Development, v. 5, no. 1, 2014. https://doi.org/10.4172/2155-9546.1000203

Braz. J. Biol. Sci., 2020, Vol. 7, No. 17, p. 261-282. 
Bolorunduro, P. I.; Adesehinwa, A. O.; Ayanda, J. O. Adoption of improved fish preservation technologies in Northwestern Nigeria. Tropicultura, v. 23, no. 2, p. 117-123, 2005.

Britwum, A. O. The gendered dynamics of production relations in Ghanaian Coastal fishing. African Gender Institute, v. 1, no. 12, p. 69-85, 2009.

Carpenter, K. E.; De Angelis, N. (Eds.). The living marine resources of the Eastern Central Atlantic. Volume 4: Bony fishes part 2 (Perciformes to Tetradontiformes) and sea turtles. Rome: FAO, 2016. p. 2343-3124. (FAO Species Identification Guide for Fishery Purposes). Available from: <http://www.fao.org/fishery/org/fishfinder/3,1/en\#Eca2>. Accessed on: Jan. 21, 2019.

Clark, C. W.; Munro, G. R.; Sumaila, U. R. Subsidies, buybacks, and sustainable fisheries. Journal of Environmental Economics and Management, v. 50, no. 1, p. 47-58, 2005.

Crammer, G. L.; Jensen, C. W.; Southgate Jr., D. D. Agricultural economics and agribusiness. New York: John Wiley and Sons, 2001.

Dulčić, J.; Kraljević, M. Age, growth and mortality of damselfish (Chromis chromis L.) in the Eastern Middle Adriatic. Fisheries Research, v. 22, no. 3/4, p. 255-264, 1995.

Ehinmore, O. M. A history of fishing in Ondo State, 1950-1997: A case study of the Ilaje Coastal Area. Lagos: University of Lagos, 1998. (Doctoral dissertation, M. A. thesis).

Fafioye, 0. 0.; Oluajo, 0. A. Length-weight relationships of five fish species in Epe Lagoon, Nigeria. African journal of Biotechnology, v. 4, no. 7, p. 749-751, 2005.

Franco-Lopez, J.; Sanchez, C. B.; Escorcia, H. B.; Abarca-Arena, L. G.; Ferreira, T. C.; VazquezLopez, H. Biological and ecological aspects regarding Cynoscion nothus Holbrook, 1855 (Perciforms: Sciaenidae). Research Journal of Fisheries and Hydrobiology, v. 5, no. 2, p. 66-75, 2010.

Froese, R.; Pauly, D. FishBase. World Wide Web electronic publication. Version 06/2017. Available from: <http://www.fishbase.org>. Accessed on: Jan. 21, 2019.

George, F. O.; Ogbolu, A. O.; Olaoye, O. J.; Obasa, S. O.; Idowu, A. A.; Odulate, D. O. Fish processing technologies in Nigeria: A case study of Ibeju-Lekki Local Government Area, Lagos State. American Journal of Food and Technology, v. 9, no. 6, p. 302-310, 2014. https://doi.org/10.3923/ajft.2014.302.310

González-Gándara, C.; Perez-Diaz, E; Santos-Rodríguez, L.; Arias-González, J. E. Lengthweight relationships of coral reef fishes from the Alacran Reef, Yucatan, Mexico. Naga, v. 26, no. 1, p. 14-16, 2003.

ILO - International Labour Organisation. Tackling child labour in domestic work: A handbook for action for domestic workers and their organizations. Jakarta: ILO, 2017.

Jones, C. M. Age and growth. In: Fuiman, L. A.; Werner, R. G. (Eds.). Fishery Science: The unique contributions of early life stages. Oxford: Blackwell, 2002. p. 33-63.

Kalirajan, K. On measuring economic efficiency. Journal of Applied Econometric, v. 5, p. 75-85, 1990.

Kigbu, A.; Ibrahim, H. Y.; Madaki, R. D.; Ogezi, E. Socio-economic activities of fishing communities and its effects on the status of fishery resources in Lake Feferuwa Nasarawa State, North Central, Nigeria. Livestock Research for Rural Development, v. 26, no. 12, 2014. Available from: <http://www.lrrd.org/lrrd26/12/kigb26226.html>. Accessed on: Jan. 24, 2019. 
Konan, K. F.; Ouattara, A.; Ouattara, M.; Gourcne, G. Weight-length relationship of 57 fish species of the coastal rivers in South-Eastern of Ivory Coast. Ribarstvo, v. 65, p. 49-60, 2007.

Kouadio, J. K.; Tapé Gnahoré, T. J.; Soumaïla, S.; Luaia, L.; Lohith, K. Stock assessment of the bigeye grunt Brachydeuterus auritus (Valenciennes, 1832) in the coastal water of Ivory Coast. International Journal of Agricultural Policy and Research, v. 3, no. 5, p. 222-230, 2015.

Koutrakis, E. T.; Tsikliras, A. C. Length-weight relationships of fishes from three Northern Aegean Estuarine Systems (Greece). Journal of Applied Ichthyology, v. 19, no. 4, p. 258-260, 2003.

Lawson, O. E.; Olusanya O. M. Fish diversity in three tributaries of River Ore, South West, Nigeria. World Journal of Fish and Marine Sciences, v. 2, no. 6, p. 524-531, 2010.

Le Cren, E. D. The length-weight relationship and seasonal cycle in gonad weight and condition in the perch (Perca fluviatilis). The Journal of Animal Ecology, v. 1, p. 201-219, 1951.

Mathew, S. Small-scale fisheries perspectives on an ecosystem-based approach to fisheries management. In: Sinclair, M.; Valdimarsson, G. (Eds.). Responsible fisheries in the marine ecosystem. Rome: FAO, 2003. (FAO Fisheries Report, 658).p. 47-63.

Morey, G.; Moranta, J.; Massutı, E.; Grau, A.; Linde, M.; Riera, F.; Morales-Nin, B. Weightlength relationships of littoral to lower slope fishes from the Western Mediterranean. Fisheries Research, v. 62, no. 1, p. 89-96, 2003.

Neimanis, A. Gender mainstreaming in practice: A handbook. 2. ed. Bratislava, Slovak: NEPAD, 2005.

Nieto-Navarro, J. T.; Zetina-Rejon, M.; Arreguin-Sanchez, F.; Arcos-Huitron, N. E.; PenaMessina, E. Length-weight relationships of demersal fish from the Eastern Coast of the Mouth of the Gulf of California. Journal of Fisheries and Aquatic Science, v. 5, no. 6, p. 494-502, 2010.

Nigeria. Centre for Laws of the Federation. Child's Right Act. Laws of the Federation of Nigeria Enactments. 2015. Available from: <http://lawnigeria.com/LawsoftheFederation/ Child-Right-Act,-2003.html>. Accessed on: Jan. 21, 2019.

Odat, N. Length-weight relationship of fishes from coral reefs along the coastline of Jordan (Gulf of Aqaba). Naga, v. 26, no. 1, p. 9-10, 2003.

Olaoye, O. J.; Idowu, A. A.; Omoyinmi, G. A. K.; Akintayo, I. A.; Odebiyi, O. C.; Fasina, A. O. Socio-economic analysis of artisanal fisher folks in Ogun Water-Side Local Government Areas of Ogun State, Nigeria. Global Journal of Science Frontier Research Agriculture and Biology, v. 12, no. 4, p. 8-22, 2012.

Olomola, A. S. Capture fisheries and aquaculture in Nigeria: A comparative economic analysis. In: Doss, C.; Olson, C. (Eds.). African rural social sciences research networks: Issues in African rural development. Arkansas: Winrock International Institute for Agricultural Development, 1991. p. 343-361.

Pauly, D. Some simple methods for the assessment of tropical fish stocks. Rome: FAO, 1983. (FAO Fisheries Technical Paper, 234). 
Pollerspöck, J.; Straube, N. Bibliography database of living/fossil sharks, rays and chimaeras (Chondrichthyes: Elasmobranchii: Holocephali) host-parasites list/parasite-hosts list. Version 4, 2015. Available from: <http://www.sharkreferences.com>. Accessed on: Jan. 21, 2019.

Seijo, J. C.; Defeo, O.; Salas, S. Fisheries bioeconomics: Theory, modelling and management. Rome: FAO, 1998.

SFLP - Sustainable Fisheries Livelihoods Programme. Contribution of fisheries research to the improvement of livelihoods in West African fisheries communities, case study: Nigeria. Rome: SFPL/DFID-FAO, 2002.

Shettima, B. G.; Mohammed, S. T.; Ghide, A. A.; Zindam, P.L. Analysis of socio-economic factors affecting artisanal fishermen around Lake Alau, Jere Local Government Area of Borno State, Nigeria. Nigerian Journal of Fisheries and Aquaculture, v. 2, no. 1, p. 48-53, 2014

Sikoki, F. D. Fishes in Nigerian waters: No place to hide. Port Harcourt: University of Port Harcourt, 2013. (Inaugural Lecture Series, 100). Available from: $<$ https://www.uniport.edu.ng/files/Inaugural Lectures/100th Inaugural Lecturre 31st January, 2013.pdf>. Accessed on: Jan. 21, 2019.

Silvestre, G. T.; Garces, L. R.; Stobutzki, I; Ahmed, M.; Valmonte-Santos, R.; Luna, C. Z.; Zhou, W. South and South-East Asian coastal fisheries: their status and directions for improved management: Conference synopsis and recommendations. Worldfish Center Conference Proceedings, v. 67, no. 1, p. 1-40, 2003.

Torell, E.; Owusu, A.; Okyere, N. A. USAID/Ghana Sustainable Fisheries Management Project (SFMP). Ghana fisheries gender analysis. Narragansett, RI: Coastal Resources Center, Graduate School of Oceanography, University of Rhode Island, GEN002, 2015.

Torres, F. Tabular data on marine fishes from Southern Africa. Part 1. Length-weight relationships. Fishbyte, v. 9, no. 1, p. 50-53, 1991.

Weatherley, A. H.; Gill, H. S.; Casselman, J. M. The Biology of fish growth. London: Academic Press, 1987.

Zar, J. H. Biostatistical analysis. New York: Prentice-Hall, 1984.

License information: This is an open-access article distributed under the terms of the Creative Commons Attribution License, which permits unrestricted use, distribution, and reproduction in any medium, provided the original work is properly cited. 